\title{
АНАЛІТИЧНА СОЦІАЛЬНА ФІЛОСОФІЯ ПРО КОЛЕКТИВНІ ФЕНОМЕНИ
}

\section{В.В. Навроцький}

Останнім часом у світовій соціальній філософії загострився інтерес до колективних дій членів груп, організацій і соціальних інституцій i, відповідно, до колективного виміру свідомості $[4,5,7,8,9]$. Це питання отримало певне висвітлення і в українській соціальній філософії [1]. Необхідність подолання сучасної кризи духовності в Україні спонукає до продовження поглибленого вивчення колективної діяльності та колективного виміру свідомості, вивчення опозиції колективне/індивідуальне в структурі особистості. У даній статті розглядаються особливості деяких колективних ментальних феноменів і зроблена спроба продемонструвати ефективність застосування засобів аналітичної соціальної філософії для вивчення колективної діяльності.

Специфіку колективної діяльності розглянемо на прикладі етносів. В останній час етнічність усе активніше виявляє себе в публічній сфері, чинник етнічності усе частіше залучається для пояснення багатьох питань політичного й економічного життя суспільства, для розробки соціальних технологій. Етнічність значною мірою проявляється насамперед у колективних діях. Колективна етнічна поведінка породжує етносенси культури - «ми-сенси» [2, с. 17-18]. Звісно, не всі «мисенси» $є$ етносенсами, але усі етносенси $є$ «ми-сенсами». Через колективну поведінку легше засвоюються етнічні норми і цінності, формується відповідальність членів етносу. Через заохочення і покарання у представників етносу формуються уявлення про зразки взаємодії i, отже, колективність надає етнічній поведінці певної стійкості. Колективні дії сприяють зміцненню відносин співробітництва і спільної підтримки, у колективній поведінці реалізується групова солідарність.

Актуальні проблеми духовності: зб. наук. праць / Ред.: Я.В. Шрамко Вип. 10. - Кривий Ріг, 2009, 293-301 
Колективні дії роблять прозорими відносини між групами поліетнічного суспільства. Відомо також, що колективні дії формують те, що потім сприймається нащадками як досвід попередніх поколінь, через який значною мірою визначається відношення етносу до внутрішніх i зовнішніх подій.

У колективних діях, наприклад, в обрядах, найбільш повно виражаються такі етноутворюючі ознаки як загальне походження, психічний склад етносу - передаються, засвоюються і, отже, зберігаються почуття, уявлення, думки предків. Обряд зв'язує між собою всіх його безпосередніх учасників, а також приєднує до них віддалені у часі покоління. Найбільш повно етнічність виявляє себе у взаємодії етносів, тому аналіз дій, спрямованих на представників іншої групи (чи на всю групу в цілому), є одним з найбільш ефективних інструментів етнічної ідентифікації індивідів і груп. При поясненні такої ідентифікації зазвичай спираються на такі показники: індивіди певної етнічної групи розпізнають один одного як членів своєї групи, знають, хто не входить до їх групи, знають, в яку групу входять «інші», припускають, що ці «інші» також мають відповідне знання, тобто припускають наявність спільного знання стосовно границь етнічних груп [5, с. 4]. Однак таке пояснення формування феномену «ми» і його протиставлення феномену «не-ми» не є специфічним для етнічної ідентифікації, бо воно може бути застосоване і для характеристики інших груп, наприклад, політичних партій.

Так чи інакше, цінність аналізу колективної поведінки, навіть безвідносно до етнічності, полягає вже в тому, що він полегшує ідентифікацію групи і моніторинг їі діяльності. 3 іншого боку, виникає питання, а що дає фіксація етнічного виміру дій для розуміння колективної поведінки, колективного характеру дій? Для прогнозування колективної дії важливо знати умови координації дій окремих індивідів, умови їх можливого роз'єднання, їхні упередження і преференції. Етнічна ідентифікація виступає суттєвою передумовою колективної дії, формуючи спільні знання та колективні преференції членів групи, полегшуючи координацію їхніх дій, визначаючи тим самим ефективність колективної дії [5, с. 9, 11-12]. 3 приводу останнього можна зауважити, що існує безліч прикладів на користь того, що згуртованість членів групи буде міцнішою саме тоді, коли індивіди входять до одного й того ж етносу, але можна навести приклади не меншого ступеня солідарності і для етнічно змішаних груп. Високий рівень солідарності може бути забезпечений фінансовим фактором, як це має місце, наприклад, для футбольного клубу, що складається переважно із легіонерів. I навіть такий 
фактор, як почуття відповідальності за власне життя і за життя своїх товаришів, не відрізняє етнічну групу, наприклад, від міжнародного космічного екіпажу. Проте, поза всім іншим, етнічна солідарність має більш стійкий «міжгенераційний» характер. Чим відрізняється етнічна колективна дія від звичайної колективної (неетнічної) дії? Статус етнічної дії може приписуватися колективній дії на різних підставах. Але, знов-таки, найбільш важливим компонентом такої дії є її спрямованість на іншу етнічну групу, вплив на неї, який прямо чи непрямо торкається ï інтересів. Так чи інакше, ця дія є опосередкованою знанням одними індивідами характеру етнічності інших індивідів.

Окреме питання - вплив етнічності на політичну дію. Етнос $\epsilon$ i суб'єктом, і об'єктом політичної дії. У політиці етнічність експлуатується, в основному, з метою стабілізації чи дестабілізації поточної соціальної ситуації, консолідації і мобілізації населення чи його деморалізації і роз'єднання. 3 цією метою деякі аспекти (ознаки) етнічності можуть бути навмисно гіпертрофовані, а то й сконструйовані [5, c. 14]. Держава, партія чи якийсь політичний лідер можуть приписувати відповідним індивідам потрібні характеристики, щоб вдало маніпулювати свідомістю цих індивідів. Індивіди можуть також самостійно і навмисно віднести себе до якогось етносу, заявивши тим самим про відносно стійку й етнічно забарвлену систему своїх уявлень і оцінок. Хоча, звісно, етнічність не може бути повністю сконструйованою.

Етнічність експлуатується у політиці саме через її «вплив на здатність груп утягнутися в колективну дію» $[5$, с. 9]. Погрішності в етнічній ідентифікації можуть привести до прийняття таких рішень, наслідки яких можуть давати зворотний ефект, вести, наприклад, до мобілізації не тих, хто підтримує заплановану акцію, а тих, хто потенційно проти неї. Типовим прикладом $\epsilon$ використання етнічного фактору в організації голосування. Звісно, етнос виступає не тільки суб'єктом i об'єктом політики, а й суб'єктом і об'єктом моралі. Чинник етнічності має суттєве значення для розв'язання моральних проблем, що виникають насамперед в етнічно змішаних колективах і у взаємовідносинах різних етносів. Пояснюючи дії окремого індивіда, посилаються на інтереси його етносу. За рішення і дії людини, якщо вони спрямовані проти іншого етносу, морально відповідає весь її етнос. Можна сперечатися щодо питання, чи мають такі колективи як навмисно створена організація або соціальна інституція «моральний статус автоматично, як його має людина» $[4$, с. 29]. Але стосовно етносу можна говорити ствердно, що він його має.

Але, звісно, моральний статус етносу відрізняється від морального 
статусу окремого його представника. Етнічні колективи можуть мати моральні характеристики, які і не збігаються із моральними характеристиками їх членів, і не є похідними від них. Те, що є моральним для людини як особистості, може не бути моральним для неї як представника етносу, як і навпаки, те, що є моральним для неї як представника етносу, не обов'язково є моральним для неї як особистості. Етнос має власну моральність поряд з моральністю його представників, бо, якщо задіяти терміни цитованої авторки, як «корпоративне тіло» він може робити те, що буде відрізнятись від того, що роблять його члени, зокрема, вчиняти у такий спосіб, який не був запланований окремими його представниками $[4$, с. 23,26$]$. До того ж, моральний статус етносу відрізняється від морального статусу індивіда ще й тим, що на відміну від організацій і соціальних інституцій, які не мають простого пріоритету над індивідом, етнос має такий пріоритет. По-перше, при взаємодії представників різних етносів моральна оцінка вчинків індивідів часто підмінюється моральною оцінкою їх етносів. По-друге, пріоритет етносу виражається ще й у тому, що інтереси окремої людини часто приносяться в жертву інтересам етносу.

Отже, можна навести багато підстав для констатації, що етнічна поведінка індивідів суттєво відрізняється від їхньої поведінки у спеціально створених організаціях і соціальних інституціях. Що може запропонувати аналітична соціальна філософія для пояснення специфіки етнічної поведінки? Надійним орієнтиром тут є та обставина, що специфічність етнічного колективу виявляється у його ментальності. Як різновид трансперсональності, етнічність певною мірою конституюється через спільні переконання, колективні преференції та інші споріднені ментальні феномени, утворення яких $є$ результатом сприйняття членами етносу обставин їхньої життєдіяльності. Самі ці колективні феномени значною мірою етнічно забарвлені. Їх експлікація i, отже, встановлення певної частини підстав для здійснення колективних дій, неможливі без з'ясування етнічної ідентичності.

Аналітична соціальна філософія вивчає колективні дії на підставі розуміння того, що є спільним у свідомості взаємодіючих індивідів. Вона виходить з того, що колективний вимір свідомості кожної окремої людини, який виникає у стосунках з іншими індивідами, втілюється у спільних знаннях і переконаннях, у колективних інтенціях і преференціях. Вони є підставою для індивідуального чи колективного вибору, який веде до колективної відповідальності. Неможливо чітко і остаточно відокремити індивідуальне і колективне у свідомості людини. Можна говорити лише про індивідуальний чи колективний вимір сві- 
домості. Тому, коли йдеться про колективну відповідальність чи про колективне рішення, треба усвідомлювати, що йдеться саме про колективний вимір відповідальності чи колективний вимір рішення кожної окремої людини.

Певний час в аналітичній соціальній філософії переважало переконання, що соціальна взаємодія грунтується переважно на взаємних інтерпретаціях індивідуальних когнітивних станів індивідів, що перебувають у відповідних стосунках. У наш час це переконання виглядає дуже спрощеним, бо посилання на такі інтерпретації не $є$ достатнім для розуміння того, як формуються стійкі характеристики колективної діяльності. Альтернативним засобом пояснення формування таких характеристик є застосування понять про спілъні переконання $\mathrm{i}$ колективні інтенції. Наприклад, за допомоги першого з них були визначені основні поняття аналітичної соціальної філософії - «норма», «практика», «правило», «конвенція», «роль», «група», «організація» тощо.

Індивідуалістське пояснення спільного переконання подає його як складене із потенційно нескінченної низки індивідуальних переконань: $x$ переконаний у тому, що $p ; y$ переконаний у тому, що $p ; x$ переконаний у тому, що $y$ переконаний у тому, що $p ; y$ переконаний у тому, що $x$ переконаний у тому, що $p$ і т. д. Головна проблема стосовно подібних формулювань полягає у неявному припущенні, що індивіди $є$ всезнаючими. Однак фактично вони мають обмежені когнітивні ресурси, які можуть й не дозволити їм будувати пропозиції із ітерацією (повторюванням) оператора переконання. Як індивіди можуть породжувати спільне переконання за таких обмежень? Питання про повторюваність є принциповим і для спільного переконання. Навіть якщо спільне переконання дійсно виникає з ітерації індивідуальних переконань, з того, що індивіди спільно переконані у тому, що $p$, взагалі прямо не випливає, що вони спільно переконані у тому, що вони спільно переконані у тому, що $p$ : із ітерації індивідуальних переконань не випливає ітерація спільних переконань [6].

Для розв'язання зазначених проблем було зроблене припущення, що індивід має у своєму розпорядженні деякий репертуар обчислювально виконуваних дедуктивних процедур, і запропоновано поняття віртуального переконання. Можливість існування спільного переконання виводиться саме з того, що композиція цих процедур також $є$ виконуваною: «Якщо я знаю, що ще чиясь множина віртуальних переконань породжується виконуваним обчисленням, тоді я можу включити обчислення віртуальних переконань скінченної кількості інших 
індивідів, що розмірковують, до обчислення моїх власних віртуальних переконань, не втрачаючи при цьому відомої виконуваності цього останнього обчислення» [6, с. 37$]$. Поняття віртуального переконання не виглядає занадто довільним, якщо йдеться, принаймні, про спільні переконання членів таких специфічних груп, якими є етноси.

Індивідуалістське пояснення колективних інтенцій, які також є суттєвою підставою розуміння соціального $Я$ людини, виходить з того, що зміст колективної інтенції виконати певну колективну дію визначається 1) через наявність у індивіда індивідуальної інтенції робити свою частину цієї дії, 2) через його переконання у тому, що достатня кількість членів групи будуть робити свою частину цієї дії та 3 ) через його переконання, що члени групи у колективний спосіб переконані у цьому останньому [9, с. 375]. Автори цього пояснення формулюють цілу програму для соціальних наук, прикінцевим пунктом якої $є$ визначення за допомоги колективних інтенцій понять «соціальна група», «організація», «інституція», «соціальна спільнота». Перевага такого визначення, на думку цих авторів, полягає в тому, що воно зроблене на «індивідуалістських» засадах, без будь-яких «супраіндивідуальних» понять $[9$, c. 372]. Проблема в тім, що часто буває неможливим, знов-таки, через обмеженість когнітивних ресурсів, приписати колективну інтенцію кожному члену відповідної групи. Цитовані автори пропонують приписувати її типовим представникам групи. Але тоді виникає питання, хто $\epsilon$ типовим представником групи, кого включити в коло репрезентативної підгрупи усієї групи індивідів.

Стосовно етноментальних феноменів це питання також виглядає цілком коректним. Взагалі-то не кожний представник етносу $є$ його типовим представником. Але у певних випадках, наприклад, за неприйнятної минулої поведінки якогось члена якоїсь етнічної групи, будь-який інший представник цієї групи може автоматично стати (з точки зору іншого етносу) її типовим представником. Так для кваліфікації певної дії як етнічної не $\epsilon$ важливим, хто конкретно із членів етносу її здійснив. Це той випадок, коли індивідуальна і групова ознака не розрізняються. Колективність етнічної дії, на відміну від неетнічної, полягає не в тому, що вона неможлива без участі інших індивідів. Якщо дія, яку виконує окремий представник етносу, спрямована на представника іншого етносу, вона вже у певному сенсі є колективною, за нею стоїть колектив, вона здійснена від імені колективу. Подіявши на іншу людину як на представника іншого етносу, індивід у той же час репрезентує свій етнос. Звісно, результат значною мірою залежить від усталених відносин між етносами. 
Альтернативна до індивідуалістської точки зору на спільні переконання і колективні інтенції - голістська точка зору - полягає у тому, що властивості спільної діяльності не є похідними від індивідуальних властивостей діючих індивідів. Вона має певне історичне підгрунтя. Задовго до дискусії про відношення між індивідуальними та спільними переконаннями, індивідуальними та колективними інтенціями, що відбувається в аналітичній соціальній філософії, про «колективні уявлення», «колективні вірування», «колективні почуття», «колективну душу», «колективну свідомість», які не зводяться до індивідуальних психічних станів, писали, наприклад, французькі соціологи Еміль Дюркгейм і Марсель Мос. Суть позиції, яка принципово розходиться із визначенням колективних інтенцій у термінах індивідуальних переконань та індивідуальних інтенцій, виражається у ствердженні, що колективна інтенціональність не може бути зведена до індивідуальної інтенціональності, а навпаки, остання породжується із першої [8, с. 24-25]. Передумовою виконання інтенціональної спільної дії виступає поділ індивідами інтенції діяти у певний спосіб. А для того, щоб інтенція діяти спільно поділялась індивідами, вони повинні діяти у кооперативний спосіб або бути потенційними виконавцями кооперативної діяльності. Цей підхід до розуміння колективних інтенцій демонструє засіб уникнути редукції колективної інтенціональністі до індивідуальної.

Теза про первинність індивідуальної інтенціональності, виражена у формі тези про егологічну побудову соціальної реальності, висувалась раніше феноменологічною соціологією: «Тільки по відношенню до мене певний різновид зв'язків з іншими набуває того особливого смислу, який я позначаю словом „ми“. Тільки по відношенню до „нас“, де центром є я, інші виступають як „ви“. А по відношенню до „вас“", які у свою чергу співвідносяться зі мною, виділяється третя сторона -,вони“ [3, c. 132]. До цього можна додати, що члени групи можуть поводити себе неоднаково навіть за наявності колективної інтенції виконати певну дію. Отже, теорія колективної інтенціональності знаходиться, певною мірою, в опозиції до феноменологічної соціології, яка хоч і ввела в обіг термін «ми-відношення», але розглядала його усе ж таки з позиції Я. У цьому і полягає, мабуть, одна з характерних відмінностей феноменологічної соціології від одного з джерел сучасного соціального голізму символічного інтеракціонізму Дж.Г. Міда, який у своєму аналізі соціальної взаємодії вихідним вважав поняття поведінки соціальної групи, а не окремого $\dddot{1}$ представника.

Наведені міркування щодо ролі колективних ментальних станів, 
зокрема ролі спільного знання в етнічній ідентифікації та ролі етнічності у формуванні колективних преференцій, з одного боку, і значний доробок аналітичної соціальної філософії стосовно вивчення колективних ментальних станів - з іншого, свідчать про ефективність застосування методів останньої до аналізу етносів як інтерпсихічних утворень, які не зводяться до суми індивідуальних психічних дій. Потенціал аналітичної соціальної філософії стосовно вивчення колективних феноменів був тут продемонстрований тільки на прикладі деяких колективних ментальних станів. Та цього, здається, достатньо для ствердження, що аналіз колективної діяльності засобами аналітичної соціальної філософії може суттєво сприяти поглибленому розумінню етноментальних феноменів i, взагалі, колективного виміру свідомості.

Сфера застосування понять про колективні ментальні феномени постійно розширюється. Відомо, що одним із основних каналів, через який здійснюються впливи на свідомість людини, є її уява. Через дію на уяву здійснюється ставлення в обов'язок. Відповідальність виникає як соціально поставлений чинник поведінки. З'ясування шляхів формування колективного виміру уяви, відносин уяви із переконаннями, бажаннями, інтенціями та преференціями $є$ перспективним завданням для подальших досліджень.

\section{1 Бібліографія}

[1] Крымский С.Б. Человеческий интеллект и духовность на рубеже тысячелетий // Пахомов Ю.Н., Крымский С.Б., Павленко Ю.В. Пути и перепутья современной цивилизации. - К.: Благотворительный Фонд содействия развитию гуманитарных и экономических наук «Международный деловой центр», 1998. - С. 379-409.

[2] Попов Б.В. Етнонаціональні сенси духовного оновлення // Етносоціальні трансформації в Україні: Зб. наук. ст. -Київ: Укр. Центр духовн. культури, 2003. - С. 5-38.

[3] Шюи A. Структура повседневного мышления // Социологические исследования. - 1988. - № 2. - С. 129-137.

[4] Graham K. The moral significance of collective entities // Inquiry. 2001. - 44. - P. 21-42.

[5] Humphreys M., Posner D., Weinstein J. Ethnic Identity, Collective Action, and Conflict: An Experimental Approach // http: 
apsproceedings.cup.org/Site/papers/005/005006WeinsteinJ.pdf. P. 1-28.

[6] Koons R.C. A Representational account of mutual belief // Synthese. - 1989. - 81. - P. 21-45.

[7] Miller S. Social Action: A Teleological Account.-Cambridge: Cambridge University Press, 2001.

[8] Searle J.R. The Construction of Social Reality. - NY: The Free Press, 1995.

[9] Tuomela R., Miller K. We-intention // Philosophical Studies.1988. - 53. - P. 367-389. 